\title{
PROLACTIN RESPONSE TO TRH IN DEPRESSION
}

\author{
Athanasios P. Zis*, A. Ariav Albala, Roger F. Haskett, Bernard J. Carroll \\ and NAOMI E. LOHR
}

The Department of Psychiatry, University of Michigan, Ann Arbor, Michigan, U.S.A.

(Received 5 April 1985: revised 15 August 1985)

\begin{abstract}
Summary-We studied the prolactin response to TRH in 53 unmedicated psychiatric inpatients. The prolactin response of females was significantly greater than the response of male subjects. There was no significant difference in the prolactin response to TRH between depressed patients and those with other psychiatric diagnoses. There was no significant relationship between the prolactin response to TRH and the severity of depression, the TSH response to TRH or the resistance to suppression of cortisol secretion by dexamethasone.
\end{abstract}

\section{INTRODUCTION}

THE THYROTROPIN (TSH) response to the thyrotropin-releasing hormone (TRH) in depression has been the subject of numerous studies. It is well established that the TSH response to TRH is decreased in some depressed patients (LoOsEN and PRANGE, 1982). Studies of the prolactin (PRL) response to TRH in depression are fewer and the results are less consistent: the PRL response to TRH in these patients has been reported as increased, decreased or normal (LoOSEN and PRANGE, 1982). In this study we examined the PRL response to TRH in 53 unmedicated psychiatric inpatients. In addition, we investigated the relationship between the PRL and TSH response to TRH and the relationship between resistance to suppression of cortisol secretion by dexamethasone and the PRL response to TRH.

\section{SUBJECTS AND METHODS}

We studied 53 psychiatric inpatients ( 29 women, 24 men). Subjects gave written consent to participate in the study and were drug free for at least one week (usually 10-14 days) prior to the study. Patients were euthyroid as determined by measurement of $T_{4}$ RIA, $T_{3}$ resin uptake and basal TSH. Patients who had received lithium salts in the three months preceding the study were excluded. Diagnoses were made according to the Research Diagnostic Criteria (RDC) (SPITZER et al., 1975) on the basis of all clinical information and a structured interview (SPITZER and ENDICOTT, 1975) and without access to laboratory results.

After an overnight fast, subjects were awakened between 6:30 and 7:00 a.m. An intravenous catheter was inserted between 8:00 and 8:30 a.m. and 500 $\mu \mathrm{g}$ of TRH (Relefact, Hoehst-Roussel) were injected intravenously at 9:30 a.m. Subjects remained supine in bed

\footnotetext{
*Address all correspondence to: Athanasios P. Zis, M.D., Department of Psychiatry, Vancouver General Hospital, \#204-2775 Heather St., Vancouver, B.C., Canada V5Z 1 M9.
} 
for the duration of the experiment. Blood was drawn $15 \mathrm{~min}$ and immediately before, and $15,30,60,90$ and $120 \mathrm{~min}$ after the injection. Samples were immediately centrifuged and stored at $-20^{\circ} \mathrm{C}$. PRL was mcasured by RIA using antibody and standard donated by the National Pituitary Agency, Baltimore, Maryland, U.S.A. The interassay and intraassay coefficients of variation were $6.5 \%$ and $5.5 \%$ respectively. the linear range of the assay was $0.5-200 \mathrm{ng} / \mathrm{ml}$. TSH was measured by RIA using the Kallestad TSH Kit reagents, Austin, Texas, U.S.A. Interassay and intraassay coefficients of variation were $8.8 \%$ and $6.0 \%$ respectively at a TSII concentration of $5.9 \mu \mathrm{u} / \mathrm{ml}$.

Within four days following the TRH infusion patients received dexamethasone $(1 \mathrm{mg})$ at 11:30 p.m. Cortisol was measured by the transcortin method of Murphy (MuRPHY, 1967). Interassay and intraassay coefficients of variation were $5.6 \%$ and $8.9 \%$ at a cortisol concentration of $10.15 \mu \mathrm{g} / \mathrm{dl}$.

Data were analysed by repeated measures analysis of variance using all time points. Subjects were grouped by sex and diagnosis. Additional grouping factors were the Dexamethasone Suppression Test results (DST) and $\Delta$ TSH. A cortisol level higher than $5 \mu \mathrm{g} / \mathrm{dl}$ at either 4:00 p.m. or 11:00 p.m. was considered abnormal (escape). A $\Delta \mathrm{TSH}$ value (defined as maximal TSH after TRH minus zero point baseline) equal to or below $7 \mu \mathrm{u} / \mathrm{ml}$ was considered blunted. The relationship between $\triangle P R L$ (defined as maximal PRL after TRH minus zero point baseline) and age, HRS score and $\Delta$ TSH was examined by the Pearson product moment correlation coefficient. The repeated measures analysis of variance and Pearson product moment correlation coefficient were performed after logarithmic transformation $(\log 10)$ of the hormonal values.

Thirty-two patients, 20 women and 12 men met RDC criteria for Major Depressive Disorder (MDD). The remaining 21 patients, 9 women and 12 men, served as Psychiatric Controls. Their diagnoses were as follows: Schizophrenia $n=8$ ( 2 women, 6 men), Mania $n=7$ ( 5 women, 2 men), Miscellaneous Diagnoses $n=6$ ( 2 women, 4 men). Mean age \pm SD was $39.9 \pm 14.7$ for the MDD group and $32.5 \pm 14.1$ for the Psychiatric Control group. Of the 32 patients with MDD, 21 scored at least 15 on the Hamilton Rating Scale (HRS), 17-item vesion. HRS score was missing in one patient. Of the 53 patients, 18 (12 women, 6 men) had abnormal DST results. Twelve of these 18 received a diagnosis of MDD. DST results were missing in one patient. Of the 53 patients, 12 (5 women, 7 men) had a blunted TSH response to TRH. Of these 12, six received a diagnosis of MDD.

\section{RESULTS}

There were no differences in baseline PRL levels between men and women $(F=0.2$, df $1,51, \mathrm{~ns})$, or between patients with MDD and psychiatric controls $(F=0.1$, df $1,51, \mathrm{~ns})$. The administration of $500 \mu \mathrm{g}$ TRH stimulated PRL release $(F=248.5$, df $6,294, p<$ $0.0001)$ (Fig. 1). There was a significant main effect for sex $(F=8.1$, df $1,49, p<0.01)$. Neither the main effect for diagnosis $(F=0.0$, df $1,49, \mathrm{~ns})$ nor the sex by diagnosis interaction $(F=0.4$, df 1,49 , ns) were significant. There were no signifcant differences in the PRL response to TRH between patients with normal and abnormal DST results $(F=1.7, \mathrm{df} 1.48$, ns) nor between patients with a normal and a blunted TSH response $(F=0.6$, df 1,49 , ns). There were also no significant differences in the PRL response to TRH of MDD patients with a HRS score above or below $15(F=3.7$, df 1,29 , ns), nor between MDD patients 
PROLACTIN RESPONSE TO TRH
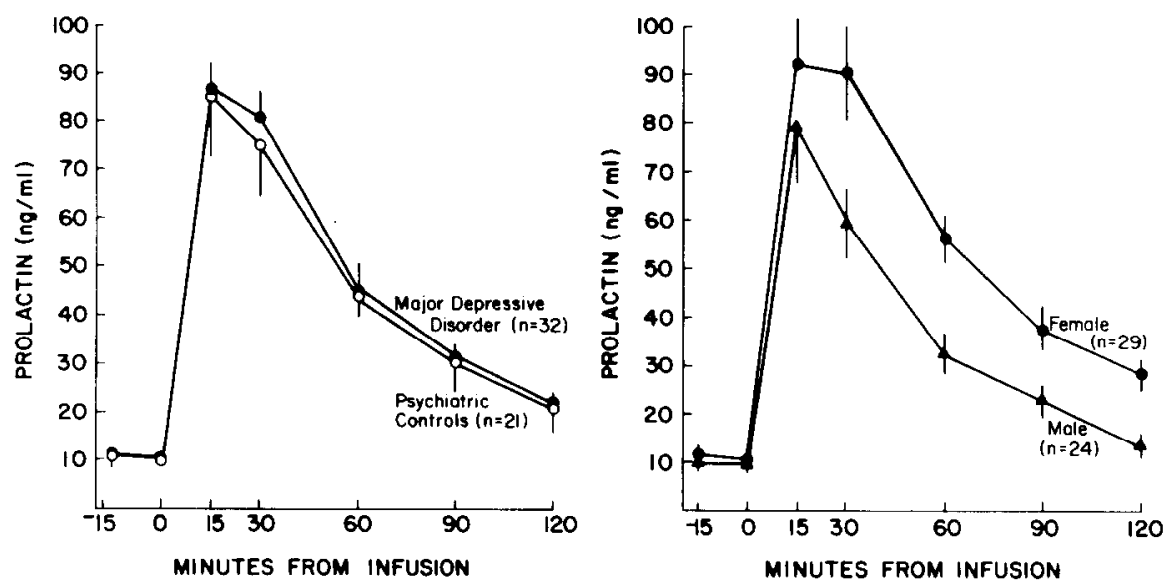

FIG 1. Prolactin response to $500 \mu \mathrm{g}$ of TRH in psychiatric inpatients $(n=53)$.

with a HRS score $\geq 15$ and manic and schizophrenic patients $(F=1.5$, df 1,34 , ns). There was a weak positive correlation between $\triangle \mathrm{PRL}$ and age $(r=0.279$, df $51, p<0.05)$. Neither the correlation between $\triangle \mathrm{PRL}$ and $\Delta \mathrm{TSH}(r=0.249, \mathrm{df} 51, \mathrm{~ns})$, nor the correlation between $\triangle \mathrm{PRL}$ and HRS score in patients with MDD $(r=-0.057$, df $29, \mathrm{~ns})$ were significant.

\section{DISCUSSION}

The data presented here indicate that there is no difference in the PRL response to TRH between patients with MDD and those with other psychiatric diagnoses. There was also no evidence that the severity of depression was associated with the PRL response to TRH. The response was significantly greater in women which is consistent with earlier reports in normal subjects (JACOBs et al., 1971). The relationship between age and PRL response although significant, accounted for only $7.8 \%$ of the variance and was not significant when data from male and female subjects were analyzed separately. Our data were insufficient to examine the relationship between ovarian status and the response of our female subjects.

Table 1 summarizes the results of previous studies of the PRL response to TRH in depression that we are able to locate and which included at least eight depressed subjects. Four studies did not include a comparison group as part of the study (EHRENSING et al., 1974; Gregoire et al., 1977; Brambilla et al., 1978; Linnolla et al., 1979). Instead, the results were compared to normative data obtained in the same laboratory in a different study or to data obtained at a different research setting. Of the studies which did include a comparison group, one reports increased response compared to healthy volunteers (MAEDA et al., 1975), one reports a decreased response in postmenopausal but normal response in premenopausal females (LiNKowsKi et al., 1980), one reports a normal response in 75\%, increased in $7 \%$ and blunted response in $18 \%$ of the depressed subjects (WINOKUR et al., 1983) and one reports a decrease response in endogenously depressed women (WITSCHY 
TABLE 1. PRL RESPONSE TO TRH: SUMMARY OF 14 STUDIES

\begin{tabular}{|c|c|c|c|}
\hline Study & $\begin{array}{c}\text { Number of } \\
\text { depressed subjects }\end{array}$ & $\begin{array}{l}\text { Number of } \\
\text { control subjects }\end{array}$ & Response \\
\hline EHRENSING et al. (1974) & 8 & 0 & $\begin{array}{l}\text { Blunted response in } \\
3 \text { patients }\end{array}$ \\
\hline MAEDA et al. (1975) & 13 & 16 healthy volunteers & Increased \\
\hline GREGOIRE et al. (1977) & 19 & 0 & Low normal \\
\hline BRAMBILLA et al. $(1978)$ & 16 & 0 & Normal \\
\hline NAEIJE et al. (1978) & 8 & $\begin{array}{l}8 \text { healthy volunteers } \\
8 \text { barbiturate coma }\end{array}$ & No difference \\
\hline Linnorla et al. (1979) & 8 & 0 & $\begin{array}{l}\text { Blunted response in } \\
7 \text { patients }\end{array}$ \\
\hline LANGER et al. (1980) & 28 & 13 healthy volunteers & No difference \\
\hline COPPEN et al. $(1980)$ & 16 & 16 healthy volunteers & No difference \\
\hline LINKOWSKI et al. (1980) & 51 & 38 healthy volunteers & $\begin{array}{l}\text { Decreased in post- } \\
\text { menopausal women } \\
\text { No difference in } \\
\text { premenopausal women }\end{array}$ \\
\hline KIRKEGAARD et al. (1981) & 18 & $\begin{array}{l}9 \text { healthy volunteers } \\
8 \text { psychiatric controls }\end{array}$ & No difference \\
\hline TARGUM et al. (1982) & 35 & 13 psychiatric controls & No difference \\
\hline WINOKUR et al. (1983) & 45 & 32 healthy volunteers & $\begin{array}{l}\text { Normal } n=34 \\
\text { Blunted } n=8 \\
\text { Increased } n=3\end{array}$ \\
\hline WITSCHY et al. (1984) & 25 & 20 healthy volunteers & $\begin{array}{l}\text { Decreased in } \\
\text { endogenously depres- } \\
\text { sed women }\end{array}$ \\
\hline ZIs et al. (present study) & 32 & 21 psychiatric controls & No difference \\
\hline
\end{tabular}

et al., 1984). The remaining five controlled studies report no difference between depressed patients and healthy volunteers or psychiatric controls (NAEIJE et al., 1978; LANGER et al., 1980; COPPEN et al., 1980; KIRKEGAARD et al., 1981; TARGUM et al., 1982). We were also unable to demonstrate a difference between our depressed subjects and psychiatric controls. This, however, does not exclude the possibility that the response of some of our depressed subjects and psychiatric controls would have been found either increased or decreased if compared to age- and sex-matched healthy volunteers studied under identical conditions. It must also be noted that some evidence for the presence of an impairment in the PRL response to TRH in depression is derived from reports of increased responsiveness on repeat testing after recovery (GREGOIRE $e t$ al., 1977; LANGER et al., 1980; KIRKEGAARD et al., 1981; D'AgatA et al., 1979; Asnis et al., 1981). Repeat testing, however, was conducted in most of these studies while many of the patients were still on tricyclic antidepressants and this finding has not been always confirmed (LINKOWSKI et al., 1980).

The administration of exogenous steroids can affect the PRL response to various stimuli including TRH (COPINSCHI et al., 1975; Sowers et al., 1977; Rossien et al., 1980). Thus, it is possible that decreased PRL response to TRH when present in certain patients, is associated with the presence of disinhibited hypothalamic-pituitary-adrenal cortex function. Unlike the results of Witschy et al. (1984), we did not find a relationship between the presence of abnormal DST results and the PRL response to TRH. The reasons for this discrepancy are not readily apparent. Finally, in this study we examined the relationship 
between the TSH and PRL response to TRH. This question is of some, at least theoretical, importance; it has been postulated that the simultaneous presence of a decreased TSH and a decreased PRL response to TRH could be the result of increased dopaminergic tone (Loosen and Prange, 1982). Few studies have addressed this question systematically. Recently TARGUM et al. (1982) and WITSCHY et al. (1984) reported an association between blunted TSH and decreased PRL response to TRH in depressed patients. LoosEN et al. (1983), however, found normal prolactin levels following TRH in depressed patients showing TSH blunting. Similarly, we were unable to demonstrate a statistically significant relationship between the TSH and PRL response to TRH. Although methodological differences (i.e. differences in sex distribution) could be responsible, the exact reasons for this discrepancy are not really apparent. Whatever the case it must be emphasized that the simultaneous presence of an attenuated TSH and PRL response does not necessarily reflect alterations in monoaminergic tone but could be the rcsult of changes in the bioavailability of TRH.

\section{REFERENCES}

Asnis, G., Sachar, F. I., Hairreich, U., Nathan, R. S., Ostrow, L., Solomon, N. and Hapern, F. S. (1981) Endocrine response to thyrotropin-releasing hormone in major depressive disorders. Psychiat. Res. 5, $205-215$.

Brambilla, F., Smeraldi, E., Sacchetti, E., Negri, F., Cocchi, D. and Muller, E. E. (1978) Deranged anterior pituitary responsiveness to hypothalamic hormones in depressed patients. Archs gen. Psychiat. 35, $1231-1238$.

Copinschi, G., L'Hermite, N., Leclerce, R., Goldstein, J., Vanhaelst, L., Virasoro, E. and Rofyn, C. (1975) Effects of glucocorticoids on pituitary hormonal response to hypoglycemia. Inhibition of prolactin release. J. clin. Endocr. Metab. 40, 442-449.

Coppen, A., Rama Rao, V. A., Bishop, M., Abou-Saleh, M. T. and Wood, K. (1980) Neuroendocrine studies in affective disorders. J. affect. Disord. 2, 311-315.

D'Agata, R. D., Pafi, C., Buongiorno, G., Gurizia, S., Marchetti, B., Gerendai, I., Poloso, P., Rapisarda, V. and ScAPAGNINI, U. (1979) Abnormal responses of prolactin to TRH stimulus in depression. In Neuroendocrine Correlates in Neurology and Psychiatry (Edited by Muller, E. E. and Agnol, A.), pp. $273-281$. Elsevier-North-Holland Biomedical Press, Amsterdam.

Ehrensing, R. H., Kastin, A. J., Schalch, D. S., Friesen, H. G., Vargas, J. R. and Schally, A. V. (1974) Affective state and thyrotropin and prolactin responses after repeated injections of thyrotropin-releasing hormone in depressed patients. Am. J. Psychiat. 131, 714-717.

Gregoire, F., Brauman, H., DeBuck, R. and Corvilain, J. (1977) Hormone release in depressed patients before and after recovery. Psychoneuroendocrinology 2, 303-312.

Jacobs, L. S., SNyder, P. J., Wilber, J. F., Utiger, R. D. and Daughaday, W. H. (1971) Increased serum prolactin after administration of synthetic thyrotropin-releasing hormone (TRH) in man. J. clin. Endocr. Metab. 33, 996-998.

Kirkegaard, C., Eskildsen, P. C. and Bjorum, N. (1981) Parallel changes of the responses of thyrotropinreleasing hormone in endogenous depression. Psychoneuroendocrinology 6, 253-259.

Langer, G., Shonbeck, G., Koinig, G., Heidemarie, R., Margot, S., Aschauer, H. and Lesch, O. (1980) Evidence for neuroendocrine involvement in the therapeutic effects of antidepressant drugs. In Progress in Psychoneuroendocrinology (Edited by BRAMBILla, F., RACAGNI, G. and DE WIED, D.), pp. 197-208. ElsevierNorth-Holland, Amsterdam.

Linkowski, P., Brauman, H. and Mendelewicz, J. (1980) Prolactin secretion in women with unipolar and bipolar depression. Psychiat. Res. 3, 265-271.

Linnolla, M., Lamberg, B. A., Rosberg, G., Karonen, S. L. and Welin, M. G. (1979) Thyroid hormones and TSH, prolactin and LH responses to repeated TRH and LRH injections in depressed patients. Acta psychiat. scand. 59, 536-544.

Loosen, P. T., Kistler, K. and Prange, A. J. (1983) Use of TSH response to TRH as an independent variable. Am. J. Psychiat. 140, 700-703.

LoOsen, P. T. and Prange, A. J. (1982) Serum thyrotropin response to thyrotropin-releasing hormone in psychiatric patients: a review. Am. J. Psychiat. 139, 405-416. 
Maeda, K., Kato, Y., Ohgo, S., Chihara, K., Yoshimoto, V., Yamaguchi, N., Kuromaru, S. and Imura, H. (1975) Growth hormone and prolactin release after injection of thyrotropin-releasing hormone in patients with depression. J. clin. Endocr. Metab. 40, 501-505.

MurPhy, B. E. P. (1967) Some studies of the protein binding of steroids and their application to the routine micro and ultramicro measurement of various steroids in body fluids by competitive protein-binding radioassay. J. clin. Endocr. Metab. 27, 973-990.

Naeije, R., Goldstein, J. Zegers De Beyl, D., Linkowski, P., Mendlewicz, J., Copinschi, G., Badawi, M., LECLERCQ, R., L'HERmIte, M. and VANHAELST, L. (1978) Thyrotropin, prolactin and growth hormone response to TRH in barbiturate coma and in depression. Clin. Endocr. 9, 49-58.

Rossier, J., French, E., Rivier, C., Shibasaki, T., Guillemin, R. and Bloom, F. E. (1980) Stress-induced release of prolactin: blockade by dexamethasone and naloxone may indicate $\beta$-endorphin mediation. Proc. natn. Acad. Sci. U.S.A. 77, 666-669.

Sowers, J. R., Carlson, H. E., Brautbar, N. and Hershman, J. M. (1977) Effect of dexamethasone on prolactin and TSH response to TRH and metoclopramide in man. J. clin. Endocr. Metab. 44, 237-241.

SPITZER, R. L. and ENDICOTT, J. J. (1975) Schedule for Affective Disorders and Schizophrenia. Biometrics Research, New York State Psychiatric Institute, New York.

Spitzer, R. L., EnDicott, J. and Robins, F. (1975) Research Diagnostic Criteria, 2nd Edn. Binmetrics Research, New York State Psychiatric Institute, New York.

TARGum, S. D., Sullivan, A. C. and Byrnes, S. M. (1982) Compensatory pituitary-thyroid mechanisms in major depressive disorder. Psychiat. Res. 6, 85-96.

Winokur, A., Amsterdam, J., Oler, J., Mendels, J., Snyder, P., Caroff, S. N. and Brunswick, D. J. (1983) Multiple hormonal response to protirelin (TRH) in depressed patients. Archs gen. Psychiat. 40, 525-531.

Witschy, J. K., Schlesser, M. A., Fulton, C. L., Orsulak, P. J., Giles, D. E., Fairchild, C., Crowley, G., Rush, A. J. (1984) TRH-induced prolactin release is blunted in females with endogenous unipolar major depression. Psychiat. Res. 12, 321-331. 